\title{
Kırşehir ilinde bulunan zirai ilaç bayilerinin mevcut durumu ve sorunlarının değerlendirilmesi*
}

\section{Evaluation of plant protection products dealers' current situation and their problems in Kırşehir province}

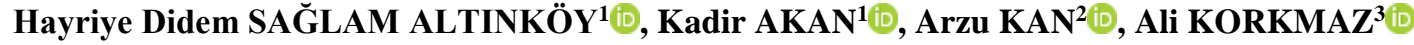 \\ ${ }^{1}$ Kırşehir Ahi Evran Üniversitesi, Ziraat Fakültesi, Bitki Koruma Bölümü, 40100, Kırşehir \\ ${ }^{2}$ Kırşehir Ahi Evran Üniversitesi, Ziraat Fakültesi, Tarım Ekonomisi Bölümü, 40100, Kırşehir \\ ${ }^{3}$ Kırşehir İl Tarım ve Orman Müdürlüğü, 40100, Kırşehir \\ Sorumlu yazar (Corresponding author): K. Akan, e-posta (e-mail): kadir_akan@ @otmail.com \\ Yazar(lar) e-posta (Author e-mail): saglamhds@gmail.com, arzu.kan@ahievran.edu.tr, akorkmaz40@hotmail.com
}

\section{MAKALE BILLGISİ}

Alınış tarihi 03 Nisan 2020

Düzeltilme tarihi 21 Temmuz 2020

Kabul tarihi 06 Ekim 2020

Anahtar Kelimeler:

Zirai ilaç bayi

Bitki koruma ürünleri

Kırşehir

\begin{abstract}
ÖZ
Tarımsal üretimde ana hedef, üretim alanından en yüksek verimi elde etmektir. Üretimde verimi etkileyen birçok biyotik ve abiyotik faktör vardır. Bu nedenle, bu etkileri azaltmak için yoğun pestisitler veya kimyasallar kullanılmaktadır. Çiftçilerin bilinçsiz bir şekilde pestisit kullanmaları dolayısıyla pestisit tüketiminde artış görülmektedir. Bilinçsiz pestisit kullanımı üretim maliyetini arttırmakta ve çevre, insan sağlığı ve hedef alınmayan organizmalar üzerinde olumsuz bir etki yapmaktadır. Zirai ilaç bayileri, bitki koruma konularında çiftçileri bilgilendiren ve çiftçiler üzerinde önemli bir etkiye sahip olan önemli şirketlerden biridir. Bu nedenle, zirai ilaç bayilerinin mevcut durumu ve sorunlarının ortaya konması gerekmektedir. $\mathrm{Bu}$ çalışma 2017-2018 yıllarında Kırşehir'de zirai ilaç bayilerinin mevcut durumlarını ve sorunlarının belirlenmesi amacıyla yapılmıştır. Bu amaçla, Kırşehir ilinde faaliyet gösteren tüm zirai ilaç bayileri ziyaret edilmiș ve yüz yüze görüșülmüștür. Elde edilen veriler SPSS paket programı kullanılarak analiz edilmiştir. Bu anketler sonucunda, zirai ilaç bayilerinin demografik yapıları, istihdam edilen personel sayıları, bayilerin mesleki yeterlik durumları ve üreticilerin sorunlarına çözüm bulma becerileri ortaya konulmuştur.
\end{abstract}

\section{ARTICLE INFO}

Received 03 April 2020

Received in revised form 21 July 2020

Accepted 06 October 2020

\section{Keywords:}

Pesticide dealers

Plant protection products

Kırşehir

\begin{abstract}
The main target in agricultural production is to get the highest yield from the production area There are many biotic and abiotic factors that affect the yield in productions. Therefore, intensive pesticides or chemicals are used to reduce these effects. Pesticide using is increasing because farmers use them in an unconscious way. The unconscious pesticide using is increasing the cost of the production and it has a negative impact on the environment, human health and non-target organisms. Plant protection product dealers are one of the important corporations that inform farmers about plant protection issues and, they have an important effect on farmers. For this reason, the current situation of Plant protection product dealers and need to be revealed to their problems. This study was conducted to evaluate current situations and finding problems of plant protection products dealers in 2017-2018 in Kırşehir. For this purpose, all plant protection products dealers were visited and interviewed face to face. These data were analysed using the SPSS package program. These questionnaires were determined the demographic structure of dealers, the number of personnel employed, the occupational proficiency status of dealers and the ability to find the solution to producers' problems.
\end{abstract}

\section{Giriş}

Tarımsal üretimde ana hedef, birim alandan kaliteli ve yüksek verim elde etmektir. Bunun için ıslah çalışmaları ile yüksek verim veren bitki materyalinin geliştirilme çalışmaları sürekli şekilde devam etmektedir. Diğer taraftan biyotik ve abiyotik faktörlerden dolayı önemli verim ve kalite kayılpları meydana gelmektedir. Bitkisel üretimde, hastalık, zararlı ve yabanc1 otlar nedeniyle her y1 ortalama \%35 kayıp meydana gelmektedir. Bu kaybın \%13'ünün zararlılar, \%12'sinin hastalık etmenleri ve \%10'unun ise yabanc1 otlardan kaynaklı olduğu bildirilmektedir (Burçak ve ark. 2015). Bu kayıpları önlemek 
için üreticiler yoğun miktarda ve bilinçsiz bir şekilde pestisit kullanabilmektedirler. Pestisitlerin bilinçsiz ve kontrolsüz kullanımı sonucu, zararlı organizmalarda dayanıklılık oluşturabilme risklerinin yanı sıra oluşan pestisit kalıntısı nedeniyle insan ve çevre sağlığına olumsuz etkileri kesinlikle göz ardı edilmemelidir.

Son yıllarda sürdürülebilir gıda güvenliği konusunda tüketicilerin daha da bilinçlenmesi ile çevre dostu bitkisel üretim ve tüketimin önemi artmıştır. Bu kapsamda yeni üretim modelleri geliştirilirken bitki koruma ürünlerinin özellikle pestisitlerin güvenli ve kontrollü kullanımı her geçen gün önem kazanmaktadır. Söz konusu riskler nedeniyle, özellikle gelişmiş ülkelerde pestisitler daha bilinçli ve kontrollü kullanılmaktadır. Bunu sağlayabilmek için, dünyanın birçok ülkesinde yasal düzenlemeler yapılmış/yapılmakta olup, bilinçli pestisit kullanımı, üreticilerin eğitimi ve bilinçlendirilmesi, pestisite uygulamalarına alternatif metotlar geliştirilmesi ve bu metotlara yönlenmesi, çevre bilincinin geliştirilmesi konularında söylemler giderek artmaktadır (Gullino ve Kuijpers 1994; Ragsdale ve Sisler 1994, Delen ve ark. 2005, Gün ve Kan 2008).

Pestisitler, 2019 yılında dünyada 84,5 milyar dolarlık bir pazar payına sahiptir (BRC 2020). Türkiye'de 2016 y1l itibariyle 4643 adet ruhsatlı bitki koruma ürünü ve 363 adet ruhsatlandırılmış etkili madde (TOB 2018) bulunmakta olup bu ürünleri satan 7184 adet zirai ilaç bayisi vardır (ZMO 2020). 2018 y1lı TÜIKK verilerine göre; satışı yapılan ürünlerin yaklaşık $\% 22.63$ 'i insektisit, \%38.40'i fungisit, \%24.65'si herbisit ve $\% 14.32$ 'i ise diğer grupları (akarisit, nematisit, rodentisitler vb.) kapsamaktadır (TÜİK 2020).

Türkiye'de y1llı ortalama 55.000 ton pestisit kullanılmaktadır. Dünyada önemli düzeyde bitkisel üretim yapan ülkelerle pestisit kullanımı karşılaştıııldığında Türkiye için düşük düzeyde pestisit tüketimi yapılmakla birlikte, tüketilen toplam pestisitin \%30 Akdeniz, \%19 Marmara, \%18 Ege, \%17 İç Anadolu, \%12 Güneydoğu Anadolu, \%3 Karadeniz ve $\% 1$ ise Doğu Anadolu'da kullanılmaktadır (Burçak ve ark. 2015). Dünyada ortalama pestisit kullanımı incelendiğinde; Japonya'da hektara $13.1 \mathrm{~kg}$, Çin'de $10.3 \mathrm{~kg}$, Hollanda da $8.8 \mathrm{~kg}$ İtalya'da 5.6 İngiltere'de $3.0 \mathrm{~kg}$ Amerika'da $2.2 \mathrm{~kg}$ iken Türkiye de 1.2 kg'dır (Burçak ve ark. 2015).

Pestisitlerin kullanımında zirai ilaç satan bayilerin etkisi dünyada önemli bir düzeydedir (Özçatalbaş ve Kutlar 2002). Amerika Birleşik Devletleri'nde yapılan araştırmalar son 10 yılda zirai ilaç ve tohum bayilerinin eğitim ve bilgi transferinde öneminin her geçen gün arttığını göstermektedir (Schmitt ve ark. 2000; Özçatalbaş ve Kutlar 2002). Türkiye'de farklı araştırıcılar tarafından zirai ilaç bayilerinin üreticilerle olan ilişkileri ve sorunları üzerine farklı çalışmalar yürütülmüştür (Y1lmaz ve ark. 1995; Erkan ve ark. 1996; Şengül 1996; Gül ve ark. 1998; İnan ve Boyraz 2003; Yetkin ve ark. 2013; Gül ve ark. 2014). Gül ve ark. (1998) Türkiye'nin önemli elma yetiştiriliş alanlarında faaliyet gösteren zirai ilaç bayilerinin küçük ölçekli, genç ve şahıs işletmeleri olduğunu ve çiftçileri tarımsal savaşım konusunda bilgilendirme faaliyetinde bulunan önemli kuruşlardan biri olduğunu belirlemişlerdir. İnan ve Poyraz (2003) Konya ilinde faaliyet gösteren "Zirai İlaç Bayileri" ile yaptıkları anket çalışmasında "Zirai İlaç Bayilerinin" tarımsal mücadele zincirinin önemli bir halkası olduğunu bildirmişlerdir.

Yürütülen bu çalışma ile de Kırşehir ili ve ilçelerinde faaliyet gösteren zirai ilaç bayilerinin yapısı, bilgi düzeyleri, karşılaştıkları sorunlar belirlenmeye çalışılmıştır. Çalışma sonucunda Kırşehir ili ve ilçelerindeki zirai ilaç bayilerinin demografik yapısı, istihdam edilen personel sayısı, bayilerin mesleki yeterlilik düzeyleri ve üretici sorunlarını nasıl çözümledikleri ortaya konulmuştur.

\section{Materyal ve Metot}

Araştırmanın, ana materyalini Kırşehir ili ve ilçelerinde (Merkez, Mucur, Kaman, Boztepe, Akpınar ve Çiçekdağ) faaliyet gösteren toplam 30 adet zirai ilaç bayisi yöneticisiyle tam sayım yöntemi ile yüz yüze görüşme suretiyle yapılan anket yolu ile elde edilen orijinal nitelikli veriler oluşturmaktadır. Zirai ilaç bayilerine ait veriler Kırşehir Tarım ve Orman İl Müdürlüğünden temin edilmiştir. Anketler zirai ilaç bayisi olarak faaliyet gösteren tüm işletmelerin yöneticileri ile yüz yüze görüşme tekniği kullanılarak elde edilmiştir. Araştırmanın yapılabilmesi için Kırşehir Ahi Evran Üniversitesi Etik Kurul'undan 01/03/2017 tarihinde 2017-02/09 karar numaras1 ile etik uygunluk alınmıştır. Araştırmaya katılan zirai ilaç bayi yetkilisine araştırmanın önemi ve amacı anlatıldıktan sonra sözel ve yazılı izin alınmıştır. Anket soruları zirai ilaç bayi yöneticilerine yöneltilerek amaca yönelik cevaplar kayıt altına alınmıştır. Zirai ilaç bayilerinden alınan veriler bilgisayar ortamında Excel programı kullanılarak oransal tablolara dönüştürülmüştür. Kesikli verilerin değerlendirilmesinde Kikare $(\chi 2)$ istatistiği kullanılmış ve hesaplanan $\chi 2$ değerleri, \%5 ve $\% 10$ önem düzeylerinde test edilmiştir. $\mathrm{Bu}$ analizlerde kullanılan $\chi 2$ istatistiğinin formülü aşağıda verilmiştir (Kesici ve Kocabaş 2007).

$$
\mathrm{X}^{2}=\sum \sum(A i j-E i j) 2 E i j c j=1 r i=1
$$

Eşitlikte Aij i. satır ve j. sütundaki gözlenen frekansı, Eij i. satir ve $\mathrm{j}$. sütunda hipoteze göre bulunması beklenen frekansı, $r$ satır sayısını, c sütun sayısını ifade etmektedir.

Çalışma sonucunda elde edilen verilerin analizi SPSS paket programı kullanılarak yapılarak literatürdeki bilgiler ışığında çözüme yönelik öneriler tartışmaya sunulmuştur.

\section{Bulgular ve Tartışma}

Kırşehir ili ve ilçelerinde yürütülen bu çalışma sonucunda değerlendirilmesi yapılan zirai ilaç bayi yöneticilerinin \%70'nin 20 yildan fazla iş tecrübesine sahip olduğu belirlenmiştir. Ankete katılan zirai ilaç bayi yöneticilerinin \%73.3'ü Yüksekokul, Lisans ve Yüksek lisans mezunu olup (Çizelge 1), bunların \%87'sinin Ziraat Fakültesi mezunu olduğu tespit edilmiştir. Ziraat Fakültesi mezunlarının ise "Bitki Koruma, Tarla Bitkileri, Bahçe Bitkileri, Tarım Makinaları Bölümlerinden" mezun oldukları belirlenmiştir. Ziraat Fakültesi mezunu olmayan zirai ilaç bayi yetkililerinin, "Tarım Ön Lisans, İktisat, Muhasebe, Pazarlama, Elektronik" gibi bölümlerin mezunu oldukları tespit edilmiştir. $\mathrm{Bu}$ veriler 1şığında, zirai ilaç bayi işletmeciliği yapanların çoğunluğunun üniversite mezunu olması ve bunlarında \%87'sinin Ziraat Mühendisi unvanına sahip olması önemli bir bulgudur. Yılmaz ve ark. (1995) yapmış oldukları çalışmada bu oranın \%27.52 olarak belirtmişlerdir. Tezcan (1996), çalışmasında Doğu Anadolu Bölgesindeki zirai ilaç bayilerinin \%17.46's1 Ziraat Mühendisi olduğunu \%37.30'unun ise eczac1 olduğunu belirlemiştir. 2000 y1lında Konya ilinde faaliyet gösteren zirai ilaç bayilerinin \%39.27'si ziraat mühendisi, \%17.09'u ziraat teknikeri \%43.64 ise tarımsal konulara uzak kişiler tarafindan 
Çizelge 1. Kırşehir ilinde anket yapılan zirai ilaç bayi yöneticilerine ilişkin genel bilgiler ve bitki koruma konularına yaklaşımları.

Table 1. General information about pesticide dealer managers surveyed in Kırşehir province and approaches to plant protection issues.

\begin{tabular}{|c|c|c|}
\hline Faktörler & İfadeler & Oran\% \\
\hline \multirow{3}{*}{ Öğrenim Durumu Oran (\%) } & Ortaokul-Lise & 26.7 \\
\hline & Yüksekokul-Lisans-Y. Lisans & 73.3 \\
\hline & Toplam & 100.0 \\
\hline \multirow{3}{*}{$\begin{array}{l}\text { Zirai ilaç bayilerinin ruhsat alma } \\
\text { yılı }(\%)\end{array}$} & 2000 y1lından önce & 40.0 \\
\hline & 2000 y1lından sonra & 60.0 \\
\hline & Toplam & 100.0 \\
\hline \multirow{5}{*}{$\begin{array}{l}\text { Zirai ilaç bayi izni verilirken dikkat } \\
\text { edilen kriterlerin durumu (\%) }\end{array}$} & Tecrübe & 26.7 \\
\hline & Eğitim-Tecrübe & 50.0 \\
\hline & Tecrübe-Mali İmkanlar & 16.7 \\
\hline & Ticari Bilgi & 6.6 \\
\hline & Toplam & 100.0 \\
\hline \multirow{5}{*}{$\begin{array}{l}\text { Zirai ilaç bayilerinin satışını yaptığı } \\
\text { girdiler ve bunların satıştaki payı } \\
(\%)\end{array}$} & Pestisit & 40.0 \\
\hline & Gübre & 35.0 \\
\hline & Tohum & 19.0 \\
\hline & Tarımsal ekipman & 6.0 \\
\hline & Toplam & 100.0 \\
\hline \multirow{4}{*}{$\begin{array}{l}\text { Zirai ilaç bayilerinin tarım teşkilatı } \\
\text { ile iş birliği durumu }(\%)\end{array}$} & Sürekli & 90.0 \\
\hline & Ara sira & 10.0 \\
\hline & İş birliği yok & 0.0 \\
\hline & Toplam & 100.0 \\
\hline \multirow{8}{*}{$\begin{array}{l}\text { Zirai ilaç bayi yöneticilerinin } \\
\text { üreticiye yardımcı olma yöntemleri } \\
(\%)\end{array}$} & Kendi bilgisi ile & 13.3 \\
\hline & Örnek isteyerek & 13.3 \\
\hline & Kendi bilgisi ile- örnek isteyerek & 13.3 \\
\hline & Üniversite ya da tarım kuruluşuna götürerek & 13.3 \\
\hline & Kendi bilgisi ile-Üniversite ya da tarım kuruluşuna götürerek & 20.0 \\
\hline & Kendi bilgisi, Örnek isteyerek veya Üniversite ya da tarım kuruluşuna götürerek & 20.0 \\
\hline & Kendi bilgisi veya diğer & 6.8 \\
\hline & Toplam & 100.0 \\
\hline \multirow{7}{*}{$\begin{array}{l}\text { Zirai ilaç bayi yöneticilerinin } \\
\text { üreticinin sorununu tespit ve teşhis } \\
\text { konusunda kendilerini yetersiz } \\
\text { hissettiği konular (\%) }\end{array}$} & Hastalığın fungal mı, bakteriyel mi, viral mı? & 6.8 \\
\hline & Zararlının kökeninin böcek mi nematod mu akar mı? & 3.3 \\
\hline & Bitki besin elementi eksikliğinde görülen belirtilerin bazı hastalık belirtileri ile karıştırılması & 23.3 \\
\hline & Yabancı otları teşhis etme & 13.3 \\
\hline & Hastalığın fungal mı, bakteriyel mi, viral mı? Yabancı otları teşhis etme & 23.3 \\
\hline & Herhangi bir konuda eksiklik hissetmiyorum & 30.0 \\
\hline & Toplam & 100.0 \\
\hline \multirow{5}{*}{$\begin{array}{l}\text { Zirai ilaç bayilerinin satışını yaptığı } \\
\text { tarım ilaçlarının türlerine göre } \\
\text { oranı (\%) }\end{array}$} & Herbisit & 50.2 \\
\hline & Fungusit & 28.8 \\
\hline & İnsektisit & 18.3 \\
\hline & Akarisit & 2.7 \\
\hline & Toplam & 100.0 \\
\hline \multirow{5}{*}{$\begin{array}{l}\text { Zirai ilaç bayi yöneticilerinin bitki } \\
\text { koruma ile ilgili bir sorunla gelen } \\
\text { üreticiye yardımcı olma yöntemleri } \\
(\%)\end{array}$} & Kendi bilgisiyle & 40.0 \\
\hline & Örnek materyal isteyerek & 25.5 \\
\hline & Üniversite ya da ilgili tarım teşkilatına başvurma & 29.0 \\
\hline & Diğer & 5.5 \\
\hline & Toplam & 100.0 \\
\hline \multirow{5}{*}{$\begin{array}{l}\text { Zirai ilaç bayi yöneticilerine göre } \\
\text { üreticinin sorununu kendi bilgisi ile } \\
\text { çözmeye çalışırken bilgi eksikliğini } \\
\text { olduğunu düşündüğü konular (\%) }\end{array}$} & Yabancı otları teşhis etmede & 40.0 \\
\hline & Hastalığın fungal-bakteriyel- viral olduğu konusunda ayrım yapamayanlar & 33.0 \\
\hline & Bitki besin elementi eksikliğinde görülen belirtilerin hastalık belirtileri ile karıştırıldığında & 24.0 \\
\hline & Zararlının kökeninin böcek-nematod-akar olduğu konusunda & 3.0 \\
\hline & Toplam & 100.0 \\
\hline
\end{tabular}


Çizelge 1 (devamı). Kırşehir ilinde anket yapılan zirai ilaç bayi yöneticilerine ilişkin genel bilgiler ve bitki koruma konularına yaklaşımları. Table 1 (continue). General information about pesticide dealer managers surveyed in Kırşehir province and approaches to plant protection issues.

\begin{tabular}{|c|c|c|}
\hline Faktörler & İfadeler & Oran\% \\
\hline \multirow{5}{*}{$\begin{array}{l}\text { Zirai ilaç bayi yöneticilerine göre } \\
\text { üreticilerin pestisit satın alma } \\
\text { sirasında öğrenmek istediği } \\
\text { konular }(\%)\end{array}$} & Hangi dozlarda kullanıldığı & 42.0 \\
\hline & Nasıl kullanıldığı & 36.0 \\
\hline & Hangi organizmaya karşı kullanıldığı & 16.0 \\
\hline & Diğer (Fiyat-Marka vb.) & 6.0 \\
\hline & Toplam & 100.0 \\
\hline \multirow{6}{*}{$\begin{array}{l}\text { Zirai ilaç bayi yöneticilerine göre } \\
\text { üreticilerin pestisit seçimine etkili } \\
\text { olan kişi ve kurumların dağılımı } \\
(\%)\end{array}$} & Bayilerin önerisi & 31.1 \\
\hline & Diğer Üreticilerin önerisi & 28.9 \\
\hline & Üreticilerin kendi tecrübesi & 20.0 \\
\hline & Tarım kuruluşun önerisi & 13.3 \\
\hline & Diğer & 6.7 \\
\hline & Toplam & 100.0 \\
\hline \multirow{4}{*}{$\begin{array}{l}\text { Zirai ilaç bayi yöneticilerine göre } \\
\text { üreticilerin pestisit çeşidini } \\
\text { seçmede dikkat ettiği faktörler } \\
(\%)\end{array}$} & İlacın Fiyatı & 51.0 \\
\hline & Firmanın ismi & 31.0 \\
\hline & İlacın etkili maddesi & 18.0 \\
\hline & Toplam & 100.0 \\
\hline \multirow{3}{*}{$\begin{array}{l}\text { Zirai ilaç bayi yöneticilerine göre } \\
\text { üreticilerin uygulamaları hedef } \\
\text { konusundaki görüşleri (\%) }\end{array}$} & Zararlı populasyonunu tamamen ortadan kaldırmak & 30.0 \\
\hline & Zararlı populasyonunu belirli bir seviyenin altında tutmak & 70.0 \\
\hline & Toplam & 100.0 \\
\hline \multirow{5}{*}{$\begin{array}{l}\text { Zirai ilaç bayi yöneticilerinin } \\
\text { üreticilerin uyguladıkları } \\
\text { mücadele yöntemlerinin çeşitleri } \\
\text { konusundaki gözlemleri (\%) }\end{array}$} & Kimyasal & 80.0 \\
\hline & Kültürel & 12.0 \\
\hline & Mekanik & 6.0 \\
\hline & Biyolojik & 2.0 \\
\hline & Toplam & 100.0 \\
\hline \multirow{4}{*}{$\begin{array}{l}\text { Zirai ilaç bayi yöneticilerine göre } \\
\text { üreticilerin pestisitlerin etkinliği } \\
\text { konusunda ki görüşleri (\%) }\end{array}$} & Kismen & 63.4 \\
\hline & Evet & 23.3 \\
\hline & Hayır & 13.3 \\
\hline & Toplam & 100.0 \\
\hline \multirow{5}{*}{$\begin{array}{l}\text { Zirai ilaç bayi yöneticilerinin } \\
\text { üreticileri pestisitlerin etkinliği } \\
\text { konusunda bilgilendirme durumu } \\
(\%)\end{array}$} & Pestisitin son kullanma tarihinin geçtiği & 10.0 \\
\hline & Üreticinin pestisitin kullanma talimatına dikkat etmemesi & 56.7 \\
\hline & Pestisitin uygun olmayan ortamda depolanmas1 & 10.0 \\
\hline & Yanlış teşhis sonucu yanlış pestisit kullanılması & 23.3 \\
\hline & Toplam & 100.0 \\
\hline \multirow{5}{*}{$\begin{array}{l}\text { Zirai ilaç bayi yöneticilerinin, } \\
\text { çalışanlarına yönelik eğitim } \\
\text { çalışması düzenleme durumu (\%) }\end{array}$} & Her zaman & 50.0 \\
\hline & Sik sik & 20.0 \\
\hline & Nadiren & 20 \\
\hline & Hiç & 10.0 \\
\hline & Toplam & 100.0 \\
\hline \multirow{4}{*}{$\begin{array}{l}\text { Zirai ilaç firmalarının bayilere } \\
\text { yönelik çalışma düzenleme } \\
\text { durumu }(\%)\end{array}$} & Evet & 70.0 \\
\hline & Hayır & 23.3 \\
\hline & Bazen & 6.7 \\
\hline & Toplam & 100.0 \\
\hline
\end{tabular}

işletildiği belirlenmiştir (KTOBİM 2000; İnan ve Boyraz 2003). Akbay ve Yurdakul (1993) tarafından Aşağı Seyhan Ovası'nda yapılan bir çalışmada; Zirai ilaç bayilerindeki yetkililer içinde Ziraat Mühendisi olanların oranı \%33.3, ziraat teknikerlerinin oranı \%15.1 olduğunu bildirmişlerdir. Kırşehir ilinde \%87 olan bu oranın yüksek olması pestisit satışının uzman kişiler tarafından yapıldığının bir göstergesi olarak kabul edilmiştir. Bu nedenle zirai ilaç bayilerinin \%50'si bayi işletmeciliğinde hem tecrübe hem de eğitimin son derece önemli olduğunu belirtmişlerdir.

Zirai ilaç bayilerinin il merkezi ve ilçelere göre eğitim durumu Çizelge 2'de verilmiştir. Buna göre il merkezinde üniversite mezunu oranı $\% 47.37$ oranında iken ortaokul-lise mezunlarının oranı da \%31.58 ile azımsanmayacak düzeydedir. İlçe düzeyinde yapılan incelemede, \%81.82 oranında bayinin meslek yüksekokulu ve üniversite mezunu olduğu tespit edilmiştir. Söz konusu aynı oran il merkezinde ise \%68.42 olarak belirlenmiştir. Zirai ilaç bayilerinin sattıkları pestisit yanında gübre, tohum ve tarımsal ekipman satışını da yaptığı belirlenmiştir. Öğrenim seviyesi yüksek olan zirai ilaç bayilerinin sattıkları girdilerde daha fazla çeşitlendirmeyi tercih ettiği ve pestisit satış oranının daha düşük olduğu, öğrenim seviyesi daha düşük olan zirai ilaç bayilerinin ise daha fazla pestisit satışına yöneldiği belirlenmiştir (Çizelge 3). Zirai ilaç bayilerinin çoğunlukla herbisit grubu ilacı sattıkları, bunu ise 
fungusit, insektisit ve diğer zirai ilaç ürünlerinin satışının izlediği belirlenmiştir (Çizelge 4). Öğrenim seviyesi yüksek olan zirai ilaç bayileri daha fazla herbisit grubu pestisit satış1 yaparken öğrenim seviyesi daha düşük olan zirai ilaç bayilerinin ise fungusit ve insektisit grubu pestisit satışında yoğunlaştığ tespit edilmiştir (Çizelge 4).

Zirai ilaç bayi yöneticilerinin öğrenim seviyelerine ve bayinin bulunduğu lokasyona göre iş tecrübe y1lı arasındaki yapılan varyans analizi sonucu öğrenim seviyesi ortaokul-lise düzeyinde olan zirai ilaç bayileri yönetici tecrübelerinin diğer öğrenim seviyesine sahip zirai ilaç bayilerine göre daha fazla olduğu tespit edilmiştir. Özellikle 2007 yılından sonra zirai ilaç bayiliği ile ilgili ruhsat alma konusundaki yasal mevzuatın değişmesi lise mezunu zirai ilaç bayilerinin ilaç bayiliği ruhsat almasını sınırlandırmış ve bu nedenle öğrenim seviyesi sınırlı olan zirai ilaç bayilerinin ruhsatlarını önceden aldığı sonucunu ortaya koymaktadır (Çizelge 5). Zirai ilaç bayilerinin bulundukları lokasyona göre tecrübe yılı arasındaki ilişki istatistiki olarak önemli bulunmamıştır. Buna göre zirai ilaç bayinin merkezde olması veya diğer ilçelerde yer alması tecrübe yılı açısından farklılık oluşturmadığ 1 belirlenmiştir.

Üreticilerin, pestisit seçiminde çoğunlukla zirai ilaç bayi (\%31.1) ve diğer üreticilerin (\%28.9) önerisini dikkate aldığ belirlenmiştir (Çizelge 1). Üreticilerin yaklaşık yarısı uzman kişi önerisi dışında diğer üreticilerin önerisi (\%31.71) ve kendi tecrübesine göre $(\% 19.51)$ pestisit seçimini yapmaktadır (Çizelge 6). Zirai ilaç bayisinin bulunduğu yere göre üreticinin pestisit çeşidini seçmede dikkat ettiği faktörler arasındaki ilişki istatistiki olarak önemli düzeyde olmadığı belirlenmiştir. Pestisit seçiminde en önemli faktörün pestisitin fiyatı (\%51.28), ikinci önemli faktörün ise pestisit üreten firma isminin (marka) (\%30.77) olduğu belirlenmiştir (Çizelge 7). İlçeler bazında durum incelendiğinde; ilaç fiyatları $\% 50$ oranında etkili bulunmuşken, ilacın isminin (\%37.50) etkili maddeye (\%12.50) göre ilaç seçiminde daha etkili olduğu belirlenmiştir (Çizelge 7).

İncelenen zirai ilaç bayilerinde ortalama 4 kişinin çalıştığı, en fazla çalışan sayısının 7 olduğu, 5 kişiden az çalışan sayısının \%80 gibi bir oranla oldukça yüksek olduğu belirlenmiştir. Bu durum araştırma bölgesinde yer alan zirai ilaç bayilerinin küçük ölçekli işletmeler olduğunun göstergesidir. Beş ve üzeri çalışanı olan zirai ilaç bayilerinde tarım ilaçları dışındaki tarımsal girdilerin satış faaliyetlerinin daha yoğun olduğu görülmektedir. Özel (2004) tarafindan Şanlıurfa ilinde yapılan çalışmada zirai ilaç bayilerinde ortalama daimi çalışan sayısı 2.8 olarak bildirilmiştir. Buna göre ele alınan araştırma bölgesinde zirai ilaç bayisinde istihdam edilen çalışan sayısının yüksek olduğu belirlenmiştir. Zirai ilaç bayilerinin ruhsat alma yılı belirlenmiş ve buna göre bayilerin \%60'1 2000 yılından sonra faaliyete geçtiği tespit edilmiştir (Çizelge 1). Zirai ilaç

Çizelge 2. Zirai ilaç bayilerinin il merkezi ve ilçelere göre eğitim durumu.

Table 2. Educational status of pesticide dealers by province center and districts.

\begin{tabular}{ccccccccc}
\hline \multirow{2}{*}{$\begin{array}{c}\text { Zirai ilaç bayinin } \\
\text { bulunduğu lokasyon }\end{array}$} & \multicolumn{2}{c}{ Ortaokul-Lise } & \multicolumn{2}{c}{ Meslek Yüksekokulu } & \multicolumn{2}{c}{ Lisans-Yüksek Lisans } & \multicolumn{2}{c}{ Toplam } \\
\cline { 2 - 9 } & Sayı & $\mathbf{\%}$ & Sayı & $\mathbf{\%}$ & Sayı & \% & Sayı & \% \\
\hline $\begin{array}{c}\text { Merkez } \\
\text { Diğer İlçeler (Akpınar, }\end{array}$ & 6 & 31.58 & 4 & 21.05 & 9 & 47.37 & 19 & 100.00 \\
Çiçekdağ, Kaman, Mucur) & 2 & 18.18 & 4 & 36.36 & 5 & 45.46 & 11 & 100.00 \\
\hline Ortalama & $\mathbf{8}$ & $\mathbf{2 4 . 8 8}$ & $\mathbf{8}$ & $\mathbf{2 8 . 7 1}$ & $\mathbf{1 4}$ & $\mathbf{4 6 . 4 1}$ & $\mathbf{3 0}$ & $\mathbf{1 0 0 . 0 0}$ \\
\hline
\end{tabular}

Çizelge 3. Zirai ilaç bayi yöneticilerinin öğrenim seviyelerine göre satışı yapılan girdilerin çeşitlerinin payları.

Table 3. Shares of the types of inputs sold according to the education levels of pesticide dealers.

\begin{tabular}{|c|c|c|c|c|}
\hline \multirow{2}{*}{ Öğrenim Düzeyi } & \multicolumn{4}{|c|}{ Satışı Yapılan Girdilerin Payı (\%) } \\
\hline & Tarım İlacı & Gübre & Tohum & Tarımsal Ekipman \\
\hline Ortaokul-Lise & 48.75 & 28.13 & 20.00 & 3.12 \\
\hline Meslek Yüksekokulu & 50.00 & 32.50 & 15.00 & 2.50 \\
\hline Lisans-Yüksek Lisans & 29.00 & 40.71 & 20.71 & 9.58 \\
\hline Ortalama & 42.58 & 33.78 & 18.57 & 5.07 \\
\hline F Değerleri & $3.34 * *$ & 1.46 & 1.20 & $2.64 *$ \\
\hline
\end{tabular}

$* 90 \%$, ** 95\% and *** 99\% Statistically significant at the confidence limit.

Çizelge 4. Zirai ilaç bayi yöneticilerinin öğrenim seviyelerine göre satışı yapılan pestisit türlerinin payları.

Table 4. Shares of pesticide types sold according to the education levels of pesticide dealers.

\begin{tabular}{|c|c|c|c|c|}
\hline \multirow{2}{*}{ Öğrenim Düzeyi } & \multicolumn{4}{|c|}{ Satılan İlaç Türlerinin Payları (\%) } \\
\hline & Herbisit & İnsektisit & Fungusit & Diğer \\
\hline Ortaokul-Lise & 30.00 & 31.88 & 35.63 & 2.50 \\
\hline Meslek Yüksekokulu & 41.25 & 15.00 & 43.75 & 0.00 \\
\hline Lisans-Yüksek Lisans & 65.71 & 11.43 & 18.57 & 4.29 \\
\hline Ortalama & 45.65 & 19.44 & 32.65 & 2.26 \\
\hline F Değerleri & $6.14 * * *$ & $6.69 * * *$ & $5.65 * * *$ & 1.16 \\
\hline
\end{tabular}

Güven sınırında istatistiki olarak ơne

$* 90 \%, * * 95 \%$ and $* * * 99 \%$ Statistically significant at the confidence limit. 
Çizelge 5. Zirai ilaç bayi yöneticilerinin öğrenim seviyelerine ve bayinin bulunduğu yere göre iş tecrübe yill.

Table 5. Years of work experience according to the education levels of pesticide dealers and the location of the dealers.

\begin{tabular}{lcc}
\hline Öğrenim Durumu ve Zirai İlaç Bayi Lokasyonu & Tecrübe Yılı & F Değeri/T Değeri \\
\hline \multicolumn{2}{l}{ Öğrenim Durumu } & \\
\hline Ortaokul-Lise & 23.00 & \multirow{3}{*}{14.25} \\
Meslek Yüksekokulu & 13.50 & \\
Lisans-Yüksek Lisans & Zirai İlaç Bayinin Lokasyonu & \\
\hline & 16.42 & $\mathbf{0 . 2 3}$ \\
\hline Merkez & 15.91 & \\
Diğer İlçeler (Akpınar, Çiçekdağı, Kaman, Mucur) & 16.23 & \\
\hline Ortalama & &
\end{tabular}

$* \% 90, * * \% 95$ ve $* * * \% 99$ Güven sınırında istatistiki olarak önemli.

$* 90 \%$,** $95 \%$ and *** $99 \%$ Statistically significant at the confidence limit

Çizelge 6. Zirai ilaç bayinin bulunduğu lokasyona göre üreticinin pestisit seçiminde dikkate aldığı kişi/kurumlar

Table 6. Persons/Institutions that the producer takes into consideration in the selection of pesticides according to the location of the pesticide dealer.

\begin{tabular}{|c|c|c|c|}
\hline Üretici İlaç Seçiminde Dikkate Aldığı Kişi/Kurumlar & Merkez & Diğer İlçeler (Akpınar, Çiçekdağı, Kaman, Mucur) & Toplam \\
\hline Bavinin Önerisi $\quad$ Say1 & 7 & 7 & 14 \\
\hline Bayinin Onerisi & 26.92 & 46.67 & 34.15 \\
\hline \multirow{2}{*}{ Diğer Üreticilerinin Önerisi } & 10 & 3 & 13 \\
\hline & 38.46 & 20.00 & 31.71 \\
\hline \multirow[b]{2}{*}{ Üreticinin Kendi Tecrübesi } & 5 & 3 & 8 \\
\hline & 19.24 & 20.00 & 19.51 \\
\hline \multirow{2}{*}{ Tarım Kuruluşunun Önerisi } & 4 & 2 & 6 \\
\hline & 15.38 & 13.33 & 14.63 \\
\hline & 26 & 15 & 41 \\
\hline Ortalama & 100.00 & 100.00 & 100.00 \\
\hline
\end{tabular}

Ki Kare $(\chi 2):$ 2.14 S.D.: 3 P:0.54 H0: Kabul

Çizelge 7. Zirai ilaç bayinin bulunduğu lokasyona göre üreticinin pestisit çeşidini seçmede dikkat ettiği faktörler

Table 7. Factors that the producer pays attention in choosing the pesticide type according to the location of the pesticide dealer.

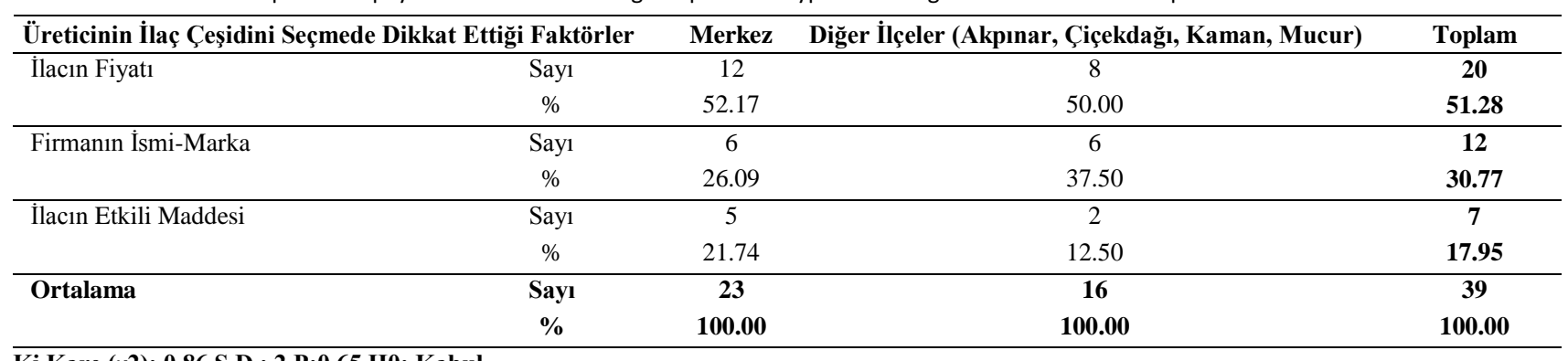

Ki Kare ( $\chi 2)$ : 0.86 S.D.: 2 P:0.65 H0: Kabul

bayi yetkililerine sorulan "İlaç bayi izni verilirken hangi konuya dikkat edilmesi gerekir" sorusuna bayi yöneticilerinin yaklaşık \%50 gibi büyük bir çoğunluğu "hem eğitim hem de tecrübeye bakılmalıdır" cevabını verirken, \%26.7'lik oranla "tecrübe yeterlidir" cevabı ikinci sırada yer almıştır. Aynı soruya zirai ilaç bayilerinin \%16.7'si ise "hem tecrübe hem de mali imkana" bakılması gerekir cevabını vermiştir (Çizelge 1). Zirai ilaç bayilerinin \%50 gibi büyük bir çoğunluğunun eğitim ve tecrübeye önem verilmesini belirtmesi bayi işletmeciliğinde eğitim ve tecrübenin son derece önemli olduğunu göstermesi bakımından anlamlidır.

Zirai ilaç bayilerine tarım teşkilatı/teşkilatları ile iş birliği içerisinde olup olmadıkları sorulduğunda \%90'1 sürekli iş birliği içerisinde olduğunu belirtirken, \%10'u ara sıra iş birliğ yaptığını bildirmiștir (Çizelge 1). Zirai ilaç bayilerinin iş birliği içerisinde oldukları kuruluşlar olarak, başta il ve ilçe tarım müdürlükleri daha sonra bitki koruma şube müdürlüğü ve ziraat fakültesinin izlediği belirlenmiştir. Zeren ve ark. (1996), Türkiye'deki zirai ilaç bayilerinin \%48'inin (yaklaşık yarısı) teknik teşkilatla sürekli, \%41'inin ara sıra iş birliği halinde olup, \%11'inin ise tarım teşkilatı ile hiçbir ilişkisinin olmadığını belirlemişlerdir. Buna göre ele alınan bölgedeki zirai ilaç bayilerinin tarım teşkilatları ile sıkı bir ilişki içerisinde olduğu görülmektedir.

Zirai ilaç bayi yöneticilerinin, "üreticinin bir sorunla kendilerine başvurduğunda yardımcı olma yöntemleri" tespit edilmeye çalışılmıştır. Bu durumda kendi bilgisi ile çözüm bulmaya çalışan \%13.3, örnek getirmesini isteyen \%13.3, üniversite ya da tarım kuruluşlardan yardım alarak çözüm arayan \%13.3, kendi bilgisi yada diğer yöntemlerle çözüm arayanlar \%6.8, kendi bilgisi yanında örnek isteyerek \%13.3, kendi bilgisi yanında üniversite ya da tarım kuruluşuna götürme 
yolunun her ikisini kullananlar $\% 20.0$ ve her üç yolu da kullananların oranı ise \%20 olarak belirlenmiştir (Çizelge 1). Sonuç olarak üreticilerin tamamının örnek materyal getirerek sorununa çözüm aramaya çalıştıkları tespit edilmiştir. İlaç bayilerinin genelinin kendi bilgisi ile üreticiye yardımcı olması, bayilerin hastalık ve zararlılar konusunda belirli düzeyde uzmanlaşmış olmalarını zorunlu hale getirmektedir. İlaç bayileri öngöremedikleri herhangi bir konuyla karşı karşıya kaldıklarında üreticiye konunun ticari yönünü de düşünerek zirai ilaç önerisinde bulunmak yerine danışabileceği kurumlara başvurmayı bir gereklilik haline getirmelidir. Araştırma bölgesinde de yaklaşık $\% 30$ oranında zirai ilaç bayisi yöneticisinin bilgisinin yeterli düzeyde olmadığı durumda tarım teşkilatı ya da üniversiteden ilgili personellere başvuru yaptıkları uygulamaları bildirmiş olup bu oran hiç de azımsanamayacak düzeydedir. Bir diğer konu ise üreticiyi yanlış yönlendiren zirai ilaç bayilerine bir daha üreticinin güvenini yitirmesidir. Bu nedenle ilaç bayileri ticari kaygıdan ziyade doğru bilgi ile üreticiye gerekli pestisitin ve olması gereken miktarı belirlenerek yönlendirmesi öncelikli ve önem seviyesi yüksek konular arasındadır. Yapılan farklı çalışmalarda üreticinin sorununu çözmede zirai ilaç bayilerinin kendi bilgisinin ön plana çıktığı bildirilmiştir (Zeren ve ark. 1996; Yiğit 2001).

Zirai ilaç bayilerinin bilgi ve birikimlerinin ne düzeyde olduğunu tespit amaciyla, kendilerine üreticinin sorununu tespit ve teşhis konusunda "Kendi bilginizden yararlandığınızda, eksikliğini hissettiğiniz bir konu var mı?” sorusu yöneltilmiştir. Görüşme yapılan yöneticilerin \%30'u herhangi bir konuda eksiklik hissetmediğini belirtirken, \%70 yönetici eksik olduğu konular olabileceğini kabul etmiştir. Bu \%70 içerisinde yer alan yöneticilere "Hangi konularda bir başkasına danışma ihtiyacı hissettikleri?" sorusu yöneltilmiştir. Buna göre ilk sırada \%23.3 oranıyla bitki besin elementi eksikliğinde görülen belirtilerin hastalık belirtileri ile karıştırılması konusunda yaşadığı yer almakta olup, bunu sirasiyla \%13.3 oraniyla yabanc1 otları teşhis edebilme konusunda zorluk yaşanması, \%6.8 oranıla hastalığın fungal-bakteriyel- viral etmenlerce oluşturulduğu konusunda ayrım yapamayanlar, \%3.3 oranıyla zararlının kökeninin böcek-nematod-akar olduğu konusunda zorluk yaşayanlar takip etmektedir (Çizelge 1). Zirai ilaç bayilerinin kendi alanında uzman olması son derece önemlidir. Aksi takdirde bir bitkideki hastalık/zararlıyı yanlış teşhis etmesi sonucu uygun olmayan çözüm yollarının önerilmesi dolayısıyla başarısız bir zirai mücadeleye yol açacaktır. Sonuç olarak üretici bu durumdan maddi ve manevi zarar görmekle birlikte bitki koruma çözüm önerileri ve ticari itibar konularında güven sorunları yaşayacaktır.

Araştırma sonuçlarına göre, Kırşehir ili ve ilçelerinde satışı yapılan tarım ilaçlarının türlerine göre paylarına bakıldığında $\% 50.2$ 'si herbisit, \%18.3'ü insektisit, \%28.8'i fungusit, \%2.7'si akarisit vd. olduğu tespit edilmiştir (Çizelge 1). Üreticilerin, zirai ilaç bayilerinden pestisit alırken $\% 42$ oranında pestisitin hangi dozda kullanılması gerektiğini, \%36 oranında nasıl kullanılacağını, \%16 oranında pestisitin hangi organizmaya karşı kullanıldığını, \%6 oranında ise pestisitin fiyatı ve markasını sorduğu belirlenmiştir. Dolayısıyla üreticilerin pestisit satın alırken bilgi sahibi olmak istedikleri belirlenmiştir.

Çalışmada zirai ilaç bayilerine "Üreticiler pestisit seçiminde kimin ya da hangi kurumun önerisini tercih etmektedir?" sorusu yöneltilmiş ve üreticilerin \%31.1 oranında bayilerin önerisine uyduğu, hastalık ve zararlının tespitine uygun pestisit veren bayiye güvendiği tespit edilmiştir. Üreticilerin azımsanamayacak kadar büyük bir çoğunluğu \%28.9 oranıyla çevresindeki diğer üreticilerin alıp kullandığ 1 ve memnun olduğu pestisitlerin isimlerini alarak bu üreticilerin önerisi doğrultusunda zirai ilaç bayisinden pestisit temin ettikleri belirlenmiştir. Kendi tecrübesine bağlı olarak bayiden pestisit temin eden üretici oranı ise yaklaşık \%20 kadardır (Çizelge 1).

Zirai ilaç bayilerine, üreticilerin pestisit çeşidini tercih ederken en çok hangi kriterlere dikkat ettiği sorusu sorulmuş ve üreticilerin pestisit tercih etmesindeki en önemli faktörün $\% 51$ 'lik bir pay ile pestisitin fiyatı olduğu belirlenmiştir. Üreticilerin pestisit seçimini etkileyen bir diğer unsur ise pestisiti üreten firmanın ismine (\%31.0) dikkat etmeleridir. Bir diğer faktör ise pestisitin içeriğinde bulunan aktif/etkin maddesidir. Üreticilerin yaklaşı \%18.0'i bu konuda teknik bilgi de gerektiren pestisitin aktif/etkin maddesini sorarak pestisit seçiminde karar vermektedir (Çizelge 1). Zirai ilaç bayi yöneticilerine "Pestisit uygulaması yaparken hedefiniz nedir?" sorusu yöneltilmiş ve yöneticilerin "\%70.0 gibi büyük bir bölümü "zararlı popülasyonunu belirli bir seviyenin altında tutmak gerekir" fikrini savunurken, \%30.0 oranında azımsanamayacak bir bölümü ise "zararlı popülasyonunu tamamen ortadan kaldırmak gereklidir" cevabını vermiştir (Çizelge 1).

Bölgedeki üreticilerin uyguladıkları "Mücadele yöntemleri arasında çoğunlukla tercih ettiği yöntemin ne olduğu" yada bu yöntemler konusunda bilgi sahibi olup olmadığı belirlenmeye çalışılmış ve elde edilen veriler ışı̆̆ında, üreticilerin $\% 80.0$ 'ninin herhangi bir zararl1, hastalık ve yabancı otla karşılaştığında öncelikle kimyasal mücadele yöntemini tercih ettiklerini, \%12.0'sinin kültürel mücadeleyi, \%6.0'sının mekanik mücadeleyi ve \%2.0'sinin ise biyolojik mücadele yönteminden yararlanmakta olduğu zirai ilaç bayilerinin verdiği bilgiye dayanılarak tespit edilmiştir (Çizelge 1). Zirai ilaç bayi yöneticilerinden elde edilen bilgiye göre; üreticilerin kimyasal mücadele dışında diğer mücadele yöntemleri hakkında yeterli bilgilerinin olmadığı ve uygulamada tercih etmedikleri elde edilen bir diğer bulgu olarak tespit edilmiştir.

Zirai ilaç bayi yöneticilerinin ifadelerine dayanılarak, Kırşehir ilinde zirai ilaç bayilerine başvuran üreticilerin yaklaşık \%23.3'ü pestisitlerin hastalık zararlı ve yabancı otların kontrolünde etkili olduğunu düşünmekte ve üreticilerin \%63.4'ünün ise pestisitlerin kısmen etkili olduğu kaygısını yaşadıkları belirlenmiştir (Çizelge 1). Zirai ilaç bayi yöneticilerine üreticilerin pestisitlerin etkinliği konusunda tereddütleri olduğu taktirde "Nasıl bir açıklama ile ikna edebilirsiniz" sorusu yöneltilmiş ve yöneticilerin \%56.7'si üreticinin "pestisit kullanma talimatına uygun şekilde kullanmadığından" kaynaklı olabileceğini açıkladıklarını belirtmişlerdir (Çizelge 1).

Zirai ilaç bayilerinin bayi bünyesinde çalışan elemanlarına yönelik eğitim çalışması düzenleme etkinlikleri incelendiğinde; $\% 50$ zirai ilaç bayi yöneticisi her zaman eğitim çalışması düzenleyerek çalışanlarını yeni ticari takdimi yapılan pestisit, yönetmelik veya sektörle ilgili konulardan haberdar ettiğini bildirmişlerdir. Zirai ilaç bayi yöneticilerinin \%90'ının farklı zaman aralıklarında da olsa değişen sıklıkla çalışanlara eğitimler düzenlediği veya düzenlenen eğitimlere gönderdiği bunun yanında $\% 10$ oranın da yöneticinin ise hiç eğitim çalışması düzenlemediği belirlenmiştir (Çizelge 1).

Zirai ilaç bayilerine "Zirai ilaç üreten firmaların ticarete konu olmuş yeni ürünleri hakkında veya sektörle ilgili eğitim çalışmaları düzenleyip size bu konuda bilgilendirir mi?" sorusu 
yöneltilmiş ve yöneticilerin \%70'i evet firmalar eğitim çalışması düzenler ve yeniliklerden haberdar eder cevabını verirken \%23.3'ü hayır firmalar eğitim çalışması düzenlemez cevabını vermiş, geri kalan \%6.7 oranında zirai ilaç bayisi yöneticisi ise firmaların arada sırada bu toplantıları yaptıklarını belirtmiştir (Çizelge 1).

\section{Sonuç}

Tarımsal üretimde birim alandan yüksek verimli ve kaliteli ürün yetiştirilmesi hedeflenmekte ve bunun için verim ve kalite kayıplarına neden olan hastalık, zararlı ve yabancı otlara karş1 üreticilerin doğru mücadele tekniklerini kullanarak zamanında mücadele etmesi gerekmektedir. Üreticilerin büyük çoğunluğu mücadele tekniği olarak kimyasal ilaç kullanma yöntemini tercih etmekte dolayısıyla, üreticilerin doğru pestisiti doğru oranda, doğru zamanda ve doğru şekilde uygulamasında zirai ilaç bayilerinin rolü büyüktür. Yapılan bu çalışma ile Kırşehir ili ve ilçelerinde faaliyet gösteren zirai ilaç bayilerinin yapısı, bilgi düzeyleri ve karşılaştıkları sorunlar belirlenmiştir. Çalışma sonucunda zirai ilaç bayi yöneticiliği yapanların \%87'si üniversitesinin Ziraat Fakültelerinden mezun kişiler olduğu tespit edilmiştir. Zirai ilaç bayilerinin tarım ilaçları dışında gübre, tarımsal ekipman ve tohum gibi tarımsal ürünleri de sattıkları belirlenmiştir. Böylece üreticiler bayiye geldiklerinde ihtiyaçları olan ürünleri tek satıcıdan temin edebilmektedir. Kırşehir ilinde faaliyet gösteren zirai ilaç bayilerinin \%90'nın tarım teşkilatı ile iş birliği içinde olduğu ve çiftçilerin sorunlarına doğru ve zamanında çözüm bulmaya çalıştıkları belirlenmiştir. Zirai ilaç bayileri, üreticilerin sorunlarını çözmede öncelikle kendi bilgi birikiminden yararlanmaktayken, çiftçi sorunlarını çözerken eksiklik hissettiği durumda ise Tarım ve Orman İl Müdürlüğü veya üniversiteye başvurduklarını belirten zirai ilaç bayi oran1 \%70 bulunmuştur. Zirai ilaç bayi yöneticileri en çok bitki hastalıklarını ve yabancı otları teşhis etmekte sorun yaşadıklarını belirtmişlerdir. Bu konuda çözüm önerisi olarak, bitki koruma konusunda yeterliliğe sahip özel sektör, Tarım ve Orman İl Müdürlüğü ve üniversite iş birliği ile bayilerimize yönelik kısa süreli eğitimler verilerek bu konudaki eksik bilgiler veya yanlışlıklar düzeltilerek üreticilere daha iyi hizmet sunulabilmesi mümkün görünmektedir. Kırşehir ili bitkisel üretim yapan üreticilerin \%80'lik bir kısmının sorununa sadece pestisit kullanarak çözüm bulabileceklerine inandıkları ve biyolojik mücadele gibi mücadele yöntemleri hakkında yeterli bilgi sahibi olmadıkları belirlenmiştir. Bu konudaki çözüm önerisi olarak zirai ilaç bayilerine ve üreticilere kimyasal mücadele yöntemleri dışındaki mücadele yöntemleri hakkında bilgilerin verildiği eğitimler düzenlenmesi önerilmektedir. Zirai ilaç bayilerinin biyolojik mücadele ajanlarının ürün yelpazelerinde yer alması gerektiği ve bunun yanı sıra üreticilerinin de biyolojik mücadele etmenlerini nas1l kullanacaklarını öğrenmesi önemli olduğu düşünülmektedir. Bu hedefe ulaşılması durumunda Kırşehir'de kullanılan pestisit kullanım miktarının düşürülmesinde katkı sağlanmış olacaktır.

\section{Teșekkür}

Bu çalışma ZRT.A4.18.022 proje numarasıyla, Kırşehir Ahi Evran Üniversitesi Bilimsel Araştırma Projeleri Birimi tarafından finanse edilmiştir. Projenin yürütülmesi sırasında desteklerini aldığımız ve burada isimlerini sayamadığımız herkese teşekkür ederiz. Bu çalışma $3^{\text {rd }}$ ICETAS (International Conference on Engineering Technology and Applied Sciences) 17-21 July 2018 Skopje-Macedonia'da sözlü bildiri olarak sunulmuştur.

\section{Kaynaklar}

Akbay C, Yurdakul O (1993) Aşağı Seyhan Ovası'nda tarımsal savaş ilaçlarının pazarlanması ve tarım işletmelerinin karşılaştıkları sorunlar. Çukurova Üniversitesi Ziraat Fakültesi Dergisi 8(1): 1328.

BRC (2020) The Business Research Company https://www.thebusinessresearchcompany.com/index.aspx. Erişim 04 Temmuz 2020.

Burçak AA, Duru AU, Örnek H (2015) Bitki Koruma Ürünleri ve Pestisit Kalıntıları. T.C. Gıda Tarım ve Hayvancılık Bakanlığı, Tarımsal Araştırmalar ve Politikalar Genel Müdürlüğü Bitki Sağlığı Araştırmaları Daire Başkanlığı, Ankara.

Delen N, Durmuşoğlu E, Güncan A, Güngör N, Burçak AA (2005) Türkiye'de pestisit kullanımı, kalıntı ve organizmalarda duyarlılık azalışı sorunları. TMMOB Ziraat Mühendisleri Odası, Türkiye Ziraat Mühendisliği VI. Teknik Kongresi, s. 629-648.

Erkan O, Yurdakul O, Gül A (1996) GAP Alanında Tarımsal Girdi Organizasyonu. Ç.Ü. Ziraat Fakültesi Güneydoğu Anadolu Projesi (GAP) Tarımsal Araştırma İnceleme ve Geliştirme Proje Paketi, Proje No: 8 , Adana.

Gullino ML, Kuijpers LAM (1994) Social and political implications of managing plant diseases with restricted fungicides in Europe. Annual Review of Phytopathology, 32: 559-579. doi: 10.1146/annurev.py.32.090194.003015.

Gül A, Şahin K, Şafak M, Yavuz O, Erdoğan N (1998) Adana ilinde tarıma girdi sağlayan kuruluşların yapısı, sorunları ve çözüm önerileri. Çukurova Üniversitesi Ziraat Fakültesi Dergisi 13(1): 4150 .

Gül M, Akpınar MG, Demircan V, Yılmaz H, Bal T, Arıcı SE, Polat M, San B, Eraslan F, Örmeci Kart ÇM, Gürbüz D, Yılmaz ŞG (2014) Zirai ilaç bayilerinin yapısı ve entegre mücadele konusundaki tutum ve davranışları. Süleyman Demirel Üniversitesi Ziraat Fakültesi Dergisi 9(1): 11-25.

Gün S, Kan M (2008) Pesticide Use in Greenhouses in Turkey: Health and environmental consciousness. Polish Journal of Environmental Studies 18(4): 607-615.

İnan H, Boyraz N (2003) Konya ilindeki zirai ilaç bayilerinin bazı yönlerden değerlendirilmesi. Selçuk Üniversitesi Ziraat Fakültesi Dergisi 17(32): 86-97.

Kesici T, Kocabaş Z (2007) Biyoistatistik. İkinci Baskı, Ankara Üniversitesi Eczacılık Fakültesi, Yayın No: 94, Ankara.

KTOBIM (2000) Konya Tarım İl Müdürlüğü, Tarımsal İstatistik Raporları, Konya.

Özçatalbaş O, Sözer İK (2002) Antalya ili Elmalı ve Korkuteli ilçelerinde tarıma girdi sağlayan kuruluşların faaliyetleri ve yayım açısından değerlendirilmesi. Akdeniz Üniversitesi Ziraat Fakültesi Dergisi 15(2): 89-100.

Özel R (2004) Şanlıurfa ilinde zirai ilaç bayilerinin pazarlama yapısı, sorunları ve çözüm önerileri. Harran Üniversitesi Ziraat Fakültesi Dergisi 8(1): 41-49.

Ragsdale NN, Sisler HD (1994) Social and political implication of managing plant disease in the United States. The Annual Review of Phytopathology 32: 545-557.

Schmitt MA, Durgan BR, Iverson SM, Minnesota P (2000) Impact Assessment and Participant Profiles of Extension's Education Programs for Agricultural Chemical/Seed Retailers and Crop Advisors. Journal of Extension 38(6) 6FEA2 http/www.joe.org/joe/2000December/a2.html. Erişim 20 Mart 2020.

Şengül M (1996) Adana ili Yüregir ovasında turunçgil üretiminde tarımsal savaş ilaçları kullanımı ve ekonomik analizi. Yüksek Lisans Tezi, Çukurova Üniversitesi Fen Bilimleri Enstitüsü, Adana. 
Tezcan H (1996) Türkiye’nin bazı illerindeki zirai mücadele ilaç bayilerinin mevcut durumu ve düşündükleri. Tarım ve Çevre İlişkileri Sempozyumu, Mersin, s. 795-800.

TOB (2018) Teoriden Pratiğe Kimyasal Mücadele. T.C. Gıda Tarım ve Hayvancılık Bakanlığı, Ankara.

TÜIKK (2020) Pesitisit tüketim miktarları http://www.tuik.gov.tr/ PreTablo.do? alt_id=1001. Erişim 20 Mart 2020.

Yetkin C, Arslan ZF, Bilgili A (2013) Şanlıurfa İlinde bitki koruma ürünlerinin kullanım durumunun ve sorunlarının belirlenmesi. I. Bitki Koruma Ürünleri ve Makineleri Kongresi. Gıda, Tarım ve Hayvancılık Bakanlığı, Gıda ve Kontrol Genel Müdürlüğü Yayınları. Ankara, 1, s. 295-307.

Yılmaz MA, Çınar A, Çınar Ö, Uygun N, Şekeroğlu E, Kornosor S, Biçici M, Özgür AF, Koç NK, Uygur FN, Baloğlu S, Karaca İ (1995) GAP Bölgesinde pilot bitki koruma kliniklerinin kurulması. GAP Bölgesi Bitki Koruma Sorunları ve Çözüm Önerileri Sempozyumu, 27-29 Nisan 1995, Şanlıurfa, s. 88-98.
Yiğit F (2001). Antalya ilinde zirai ilaç bayilerinin genel durumları ve çiftçi ile olan ilişkilerinin araştırılması, Türk-Koop. Ekin 5(15): 9096.

Zeren O, Kumbur H, Taşdemir H (1996) İçel ilinde tarımsal ilaç pazarlama kullanım tekniği ve etkinliği üzerinde araştırmalar, Tarım-Çevre İlişkileri Sempozyumu Doğal Kaynakların Sürdürülebilir Kullanımı, s. 259-269.

Zhang W, Jiang F, Ou J (2011) Global pesticide consumption and pollution: with China as a focus. Proceedings of the International Academy of Ecology and Environmental Sciences 1(2): 125.

ZMO (2020) Ülkemizde bitki koruma ürünleri ve buna bağlı konular üzerine değerlendirme http://zmo.org.tr/genel/bizden_detay.php?kod=30892\&tipi= 5\& sube $=0$. Erişim 20 Mart 2020 . 